\title{
WCZESNOŚREDNIOWIECZNY SZKLANY PACIOR Z KRUSZWICY
}

\author{
AN EARLY MEDIEVAL GLASS BEAD FROM KRUSZWICA
}

\begin{abstract}
In the gord in Kruszwica, on the settlement level from the $4^{\text {th }}$ quarter of the $11^{\text {th }}$ century, a piece of a large bead was discovered. It was made of black and purple glass, decorated with a set glass thread and small buttons with the (floral) millefiori ornament. It was made of glass, the "ash" variety of the $\mathrm{Na}_{2} \mathrm{O}-\mathrm{K}_{2} \mathrm{O}-\mathrm{CaO}-\mathrm{MgO}-\mathrm{Al}_{2} \mathrm{O}_{3}-\mathrm{SiO}_{2}$ type (the grains) and the $\mathrm{Na}_{2} \mathrm{O}-\mathrm{K}_{2} \mathrm{O}-\mathrm{CaO}-\mathrm{MgO}-\mathrm{Al}_{2} \mathrm{O}_{3}-\mathrm{PbO}-\mathrm{SiO}_{2}$ type (the ornament). An interpretation of the results of an analysis of the chemical content of the glass (XRF, X-Ray Fluorescence) has allowed to define the probable place of the glass production, as well as the form and type of this rare specimen, namely the Middle East (probably Byzantine) workshops.
\end{abstract}

Keywords: Kruszwica, early Middle Ages, gord, glass, bead, import.

\section{ZAGADNIENIA WSTĘPNE}

W roku 1968 w północnej części wczesnośredniowiecznego ośrodka grodowego w Kruszwicy (stanowisko 4) odkryto fragment dużego szklanego paciora ${ }^{1}$. Wyjątkowość tego znaleziska skłoniła autorkę do zaprezentowania okoliczności jego odkrycia, omówienia wyników badań morfologicznych i laboratoryjnych (składu chemicznego szkła) oraz próby określenia pochodzenia.

Pacior odkryto w destrukcie bliżej nieokreślonych drewnianych konstrukcji zalegających na obszarze intensywnej zabudowy 8 poziomu osadniczego, datowanego na 4. ćwierć XI wieku. Jest to okres stabilnej egzystencji jednoczłonowego, okolonego wałami grodu wraz z istniejącą już siecią pobliskich osad (ryc. 1 i 2). Od drugiej połowy XI wieku rozpoczyna się okres intensywnego rozwoju ośrodka

* ORCID 0000-0001-5515-892X, Ośrodek Studiów Pradziejowych i Średniowiecznych, Instytut Archeologii i Etnologii Polskiej Akademii Nauk, ul. Rubież 46, 61-612 Poznań, e-mail: sawicka@ man.poznan.pl.

${ }^{1}$ Określenie ,pacior” przyjęto w tym opracowaniu ze względu na duże rozmiary omawianego okazu. 


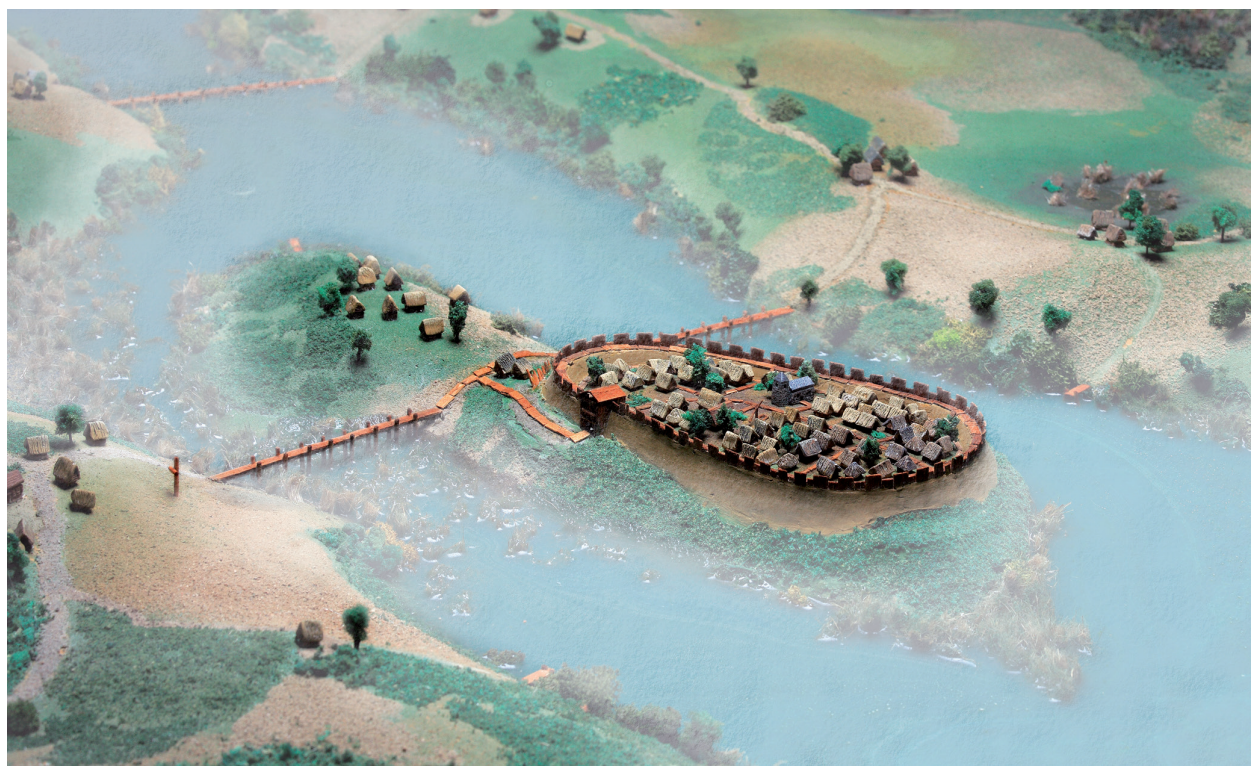

Ryc. 1. Kruszwica. Makieta XI-wiecznego ośrodka grodowego, wg ustaleń W. Dzieduszyckiego, wykonali T. i K. Sawiccy. Fot. T. Sawicki

z wieloma doskonale funkcjonującymi warsztatami wytwórczymi, m.in. dwoma pracowniami jubilerskimi działającymi tu w 1. ćwierci XII wieku, w których odkryto ślady obróbki bursztynu i metali kolorowych (Cofta-Broniewska 1962), kościołem oraz pobliską przeprawą przez Gopło. Na majdanie grodu, zwłaszcza w północnej jego części (stanowisko 4) odkryto pozostałości zwartej zabudowy z resztkami moszczonych drewnem ulic (ryc. 3). W centralnej części grodu działało także zaplecze gospodarcze budowanej świątyni pw. św. Wita, z warsztatami ceramiki budowlanej. Po roku 1093 walki dynastyczne między Władysławem Hermanem a jego synem Zbigniewem i stłumienie tego buntu powodują nagłe załamanie się roli Kruszwicy jako znaczącego centrum administracyjno-politycznego. Ośrodek ten odradza się w 1. połowie XII wieku, ale już jako prężny organizm wczesnomiejski z centrum produkcyjnym (o przeobrażeniach socjotopograficznych Kruszwicy zob. Dzieduszycki 1982, tab. 1, s. 112; zwłaszcza Dzieduszycki 1984; Dzieduszyccy 1993; 2005).

\section{FORMA PACIORA}

Zachował się znaczny fragment paciora, umożliwiający rekonstrukcję jego wyglądu (ryc. 4 i 5). Jest to duży, elipsoidalny okaz z jednym korpusem, o spłaszczonych wierzchołkach i prostym, centrycznym kanaliku równoległym do osi 


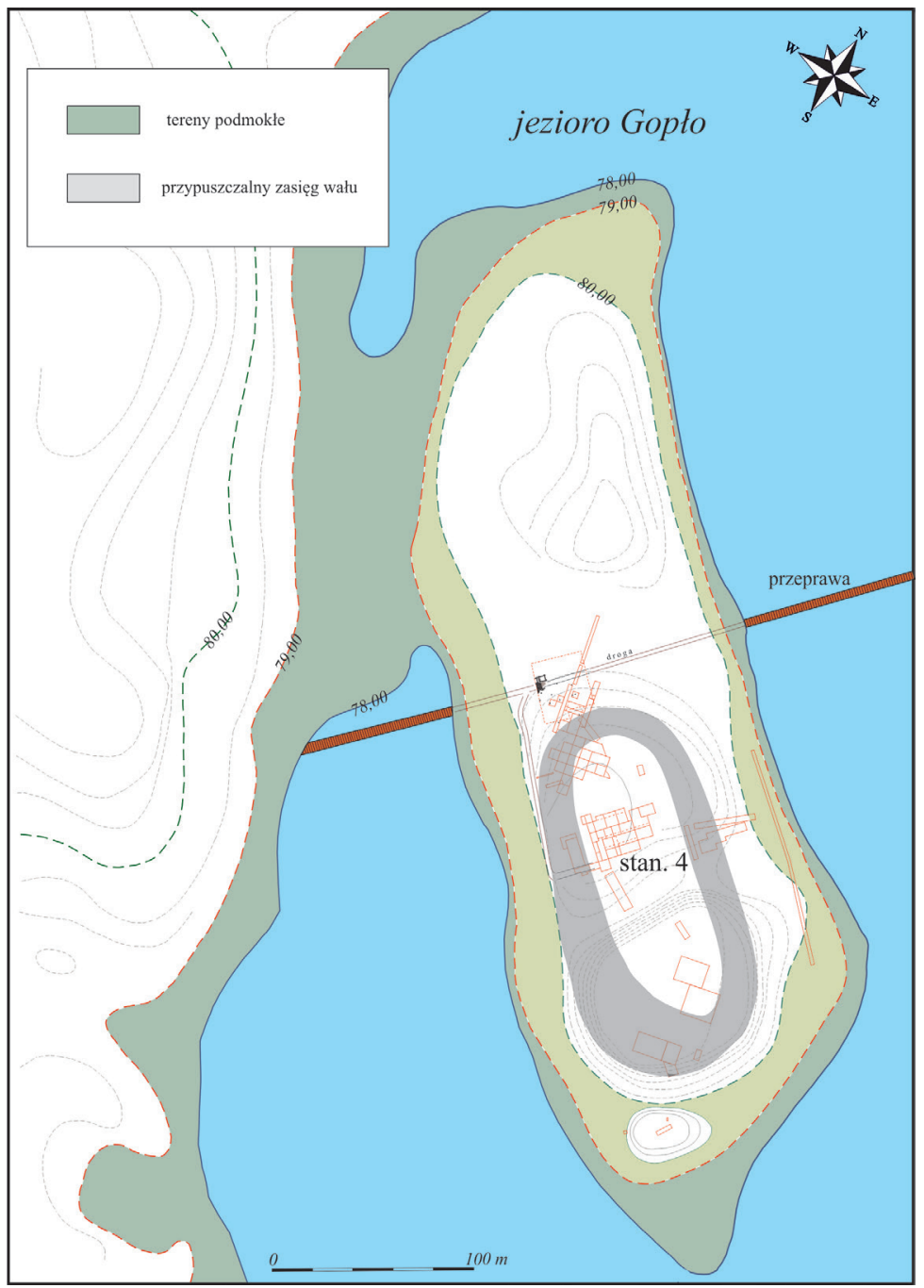

Ryc. 2. Kruszwica. Uproszczony plan warstwicowy Półwyspu Rzępowskiego, wraz z przypuszczalnym zasięgiem wałów i siatką wykopów badawczych. Rys. J. Sawicka

paciorka. Zachowała się fragmentarycznie jedna płaska krawędź przy kanaliku. Średnica paciora wynosi $38 \mathrm{~mm}$, zrekonstruowana długość $52 \mathrm{~mm}$, średnica kanalika $5 \mathrm{~mm}$. Szkło korpusu zachowało się bardzo dobrze, widoczne są niewielkie zmatowienia oraz drobne rysy powstałe przy używaniu. Szkło osnowy jest czarno-fioletowe, bardzo słabo przejrzyste.

Zachowany ornament to wtopione płasko, nieregularne, o różnej grubości, zygzakowate, prawdopodobnie dwie nici, wykonane z żółtego, opakowego szkła i trzy 


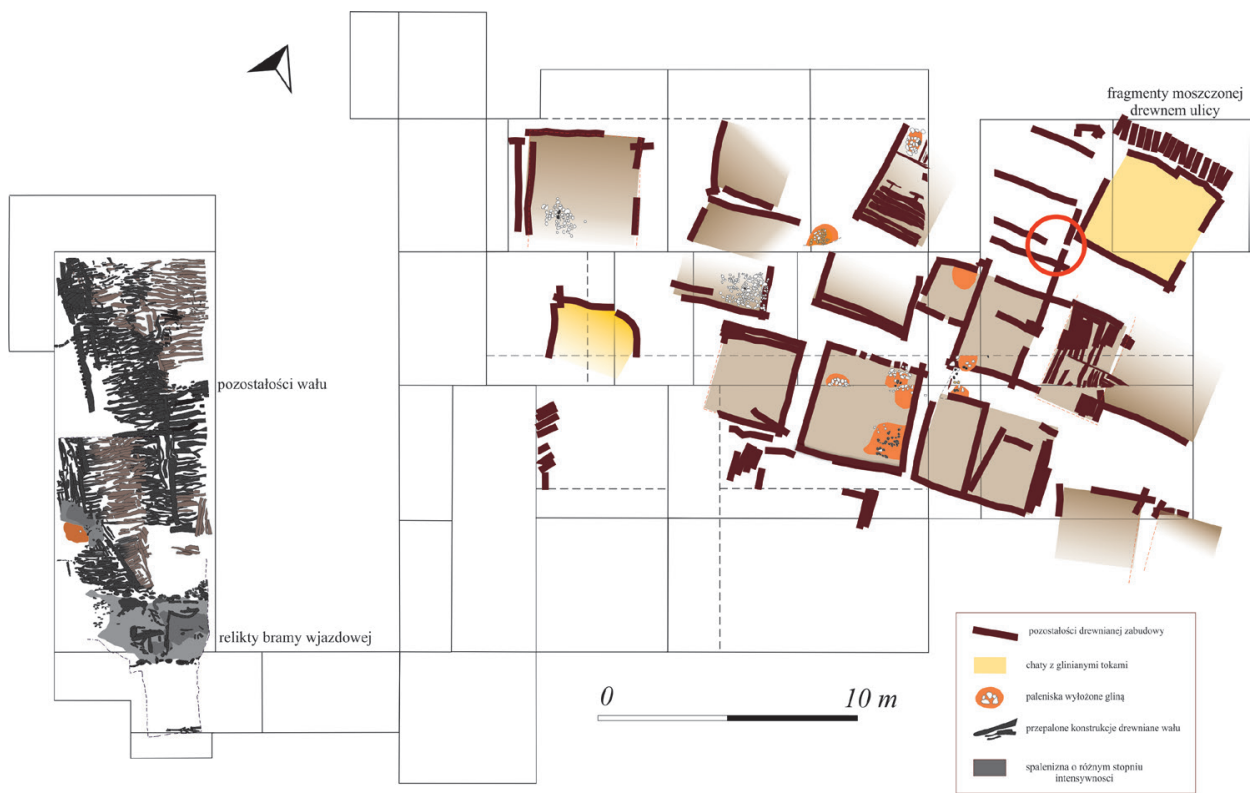

Ryc. 3. Kruszwica, stan. 4, północna część grodu. Schematyczny plan zabudowy poziomu osadniczego z 4. ćwierci XI wieku, z lokalizacją miejsca odkrycia paciora. Rys. J. Sawicka

nieregularne półkuliste guzki zdobione „kwiatowym” ornamentem. Guzki umieszczono w polach powstałych przez skrzyżowanie nitek, wskazuje na to zachowany fragmentarycznie układ ornamentu. Całkowita średnica guzków wynosi - 7, 7,1 i $6 \mathrm{~mm}$, wysokość $3 \mathrm{~mm}$. Ozdobiono je ,kwiatowym” ornamentem naprzemiennych, płasko wtopionych 24 nitek - czarnych, białych i żółtych, o szerokości około $1 \mathrm{~mm}, \mathrm{z}$ obramowanym czarną obwódką żółtym środkiem o średnicy około $2 \mathrm{~mm}$. Grubość nici waha się od 1 do $2,5 \mathrm{~mm}$. Szkło ornamentu, białe, żółte i czarne jest opakowe, dobrze zachowane.

\section{TECHNIKA WYKONANIA PACIORA}

Podczas makroskopowej obserwacji przekroju paciora zaobserwowano wyraźne ślady grubego pasma szkła, smugi oraz większe elipsoidalne pęcherze gazowe układające się prostopadle do jego osi i pojedyncze na jego powierzchni. Wskazuje to na najczęściej spotykaną metodę formowania paciorków szklanych - technikę nawijania pasma szkła na metalowy trzpień. Zachowana fragmentarycznie, spłaszczona powierzchnia przy kanaliku jest starannie zagładzona. Ornament zygzakowatych, nieregularnych nici został płasko wtopiony w osnowę. Półkuliste guzki nalepione na osnowę, wykonano z opakowego żółtego szkła. Dopiero na tak umocowany 


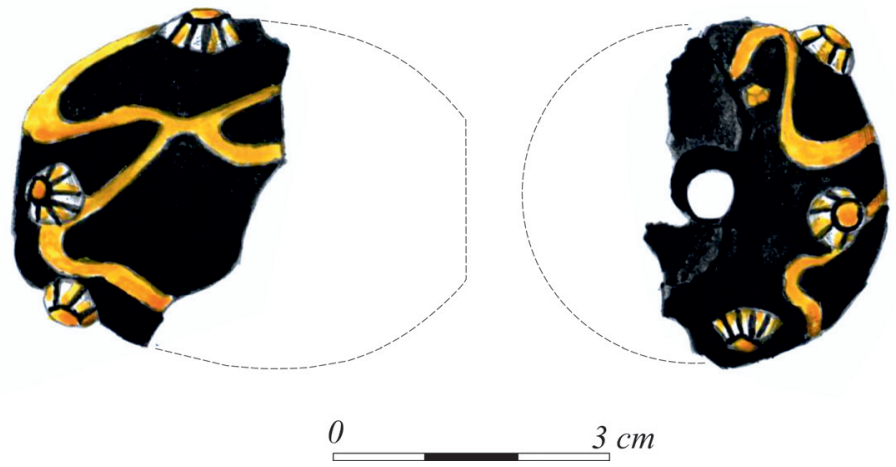

Ryc. 4. Kruszwica. Rysunkowa rekonstrukcja paciora (inw. K4/6276/68). Rys. J. Sawicka

„trzpień” nalepiono z boku płaskie, prostokątne płytki szkła millefiori imitujące płatki kwiatu (ryc. 5b). Płytki te, o grubości około 1,5 mm i wysokości około $2 \mathrm{~mm}$, są nieregularne, rozciągnięte miejscami przy aplikacji i prawdopodobnie pochodzą z tej samej macierzystej pałeczki, na co wskazuje powtarzający się, nieregularny układ poszczególnych nitek.

Rzadko spotykana wielkość, staranne i niewątpliwie pracochłonne wykonanie wskazują na rzemieślnika wykazującego się wysokimi umiejętnościami. Sam pacior ma cechy wyrobu luksusowego.

\section{Technologia wytopu szkła paciora}

Wykonano dwie fizykochemiczne analizy składu chemicznego szkła - osnowy paciora (próbka 1) i żółtej nici ornamentu (próbka 2). Zostały przebadane metodą XRF, odmianą EDS, określaną inaczej jako analiza przy użyciu mikrosondy elektronowej lub spektrometria dyspersji energetycznej ${ }^{2}$. Wyniki wraz z proporcjami i sumami głównych składników szkłotwórczych zaprezentowano w tabeli 1 i $2^{3}$.

Punktem wyjścia do rozważań nad pradziejowym i wczesnośredniowiecznym szkłem powinien być jego skład chemiczny (zob. przede wszystkim Dekówna 1980,

${ }^{2}$ Metoda ta ma charakter nieniszczący i mikroinwazyjny, pomiary przeprowadza się na powierzchni próbki, na wykonanym wcześniej niewielkim szlifie. Do badań składu chemicznego szkła stosowano ją do niedawna w Laboratorium Bio- i Archeometrii IAE PAN. Ocena składu oparta jest na wzorcach opracowanych wcześniej (używanych przez długie lata przy ilościowej analizie spektrograficznej). Określa się ilościowo, w procentach wagowych, zawartość około 17-25 tlenków, występujących w stężeniach powyżej 0,1\% (bliżej Dekówna 2005).

${ }^{3}$ Analizę wykonała Elżbieta Pawlicka w Laboratorium Bio- i Archeometrii IAE PAN. Badania wykonano na spektrometrze rentgenowskim z cyfrowym układem AVALON 8000. 


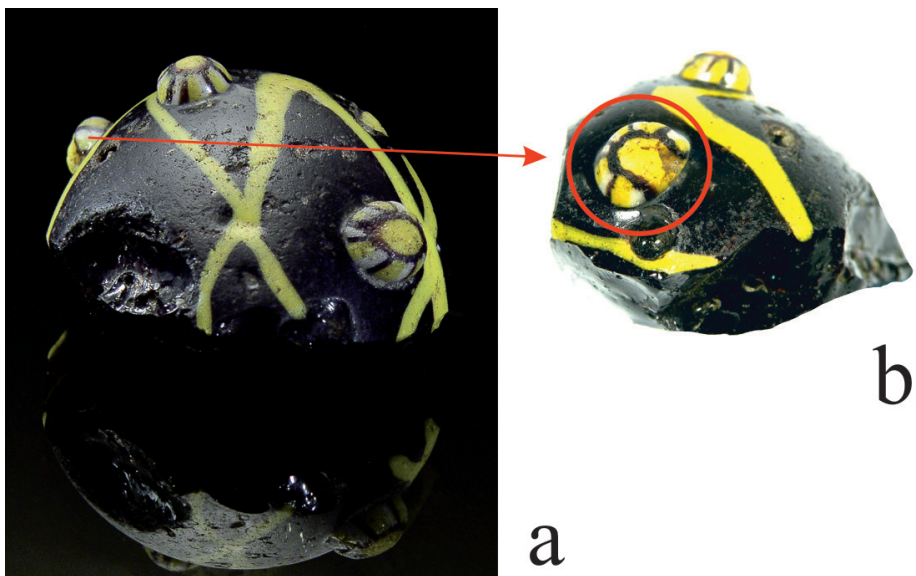

Ryc. 5. Kruszwica. Zachowany fragment paciora (a) oraz powiększenie jednego z guzków (b). Fot. M. Jórdeczka

s. 21 i nn.; Stawiarska 1984; 1987; Szczapowa 1973). Tę zasadę przyjęto w niniejszym opracowaniu. Interpretację fizykochemicznych analiz składu oraz klasyfikację szkieł oparto na pracach polskich badaczy, którzy przyjęli podstawowe kryteria określone przez rosyjską badaczkę Julię L. Szczapową (Szczapowa 1973, tab. 25; Dekówna 1980, s. 29-38; Dekówna i Olczak 2002, s. 190) ${ }^{4}$. Przy interpretacji związków odbarwiających, zamącających i barwiących, podstawą rozważań są ustalenia autorów Principes... (Dekówna i Olczak 2002, s. 192-198).

$\mathrm{Na}$ podstawie wyników analizy i przy zastosowaniu wyżej wymienionych kryteriów można stwierdzić, że zarówno szkło, z którego wykonano osnowę, jak i żółta nić dekoracyjna paciora są rodzaju sodowego, odmiany „popiołowej”. Wytopiono je przy użyciu sody pochodzenia roślinnego ${ }^{5}$. Na wspomnianą odmianę wskazuje obecność tlenku potasu $\left(\mathrm{K}_{2} \mathrm{O}\right)$ powyżej 1,3\% oraz proporcja $\mathrm{Na}_{2} \mathrm{O}: \mathrm{K}_{2} \mathrm{O}$ $<13$ : 1. Korpus wykonano ze szkła typu sodowo-potasowo-wapniowo-magnezowo-glinowo-krzemowego $\left(\mathrm{Na}_{2} \mathrm{O}-\mathrm{K}_{2} \mathrm{O}-\mathrm{CaO}-\mathrm{MgO}-\mathrm{Al}_{2} \mathrm{O}_{3}-\mathrm{SiO}_{2}\right)$, jej dekorację zaś - ze

${ }^{4}$ Klasyfikacja ta polega na wydzieleniu poszczególnych chemicznych składników szkła i określeniu ich roli w procesie powstawania szklanej masy. Obecność i ilość podstawowych składników szkłotwórczych - $\mathrm{SiO}_{2}, \mathrm{Na}_{2} \mathrm{O}, \mathrm{K}_{2} \mathrm{O}, \mathrm{CaO}, \mathrm{PbO}, \mathrm{MgO}, \mathrm{Al}_{2} \mathrm{O}_{3}-$ ma zasadniczy wpływ na właściwości szkła. Obliczenie proporcji ich występowania i zestawienie w schematy wg zasad nadrzędności i podrzędności pozwala określić rodzaj, odmianę i typ szkła. Dla podstawowych składników szkłotwórczych stężenia minimalne, które należy uwzględniać przy określaniu typu chemicznego szkieł krzemianowych, wynoszą: $\mathrm{Na}_{2} \mathrm{O}-3 \%, \mathrm{~K}_{2} \mathrm{O}-4 \%, \mathrm{CaO}-3 \%, \mathrm{MgO}-2 \%, \mathrm{Al}_{2} \mathrm{O}_{3}-2 \%, \mathrm{PbO}-5 \%$. J.L. Szczapowa uściśliła i rozszerzyła wcześniejsze klasyfikacje (Szczapowa 1973 i tam dalsza literatura).

${ }^{5}$ Sodę taką, topnik w procesie wytopu szkła, pozyskiwano z popiołów roślin halofitowych rosnących na słonych glebach, niektórych pustyniach czy solniskach. Od starożytności używano popiołów z Salicornia herbacea, Salsola czy Kalidium caspicum (o zastosowaniu popiołów roślin solilubnych do wytopu szkieł popiołowych - przede wszystkim Henderson 2013, s. 26-42; Barkoudah i Henderson 2006). 
Tabela 1. Kruszwica, stan. 4. Wyniki analizy składu chemicznego szkła sodowo-potasowo-wapniowo-magnezowo-glinowo krzemowego (próbka 1) i sodowo-potasowo-wapniowo-magnezowo-glinowo-ołowiowo-krzemowego (próbka 2)

\begin{tabular}{|c|c|c|}
\hline Przedmiot & \multicolumn{2}{|c|}{ fragment szklanego paciora } \\
\hline Nr inw. & \multicolumn{2}{|c|}{ K4/6276/1968 } \\
\hline Chronologia zespołu & \multicolumn{2}{|c|}{ ostatnia ćwierć XI w. } \\
\hline Barwa i przezroczystość szkła & \multicolumn{2}{|c|}{$\begin{array}{l}\text { szkło korpusu słabo przejrzyste, ornamentu opakowe, } \\
\text { barwa korpusu czarna, ornamentu żółta i biała }\end{array}$} \\
\hline Typ chemiczny szkła & \multicolumn{2}{|c|}{$\begin{array}{c}\text { korpus - szkło } \mathrm{Na}_{2} \mathrm{O}-\mathrm{K}_{2} \mathrm{O}-\mathrm{CaO}-\mathrm{MgO}-\mathrm{Al}_{2} \mathrm{O}_{3}-\mathrm{SiO}_{2} \\
\text { ornament żółtej nici }- \text { szkło } \\
\mathrm{Na}_{2} \mathrm{O}-\mathrm{K}_{2} \mathrm{O}-\mathrm{CaO}-\mathrm{MgO}-\mathrm{Al}_{2} \mathrm{O}_{3}-\mathrm{PbO}-\mathrm{SiO}_{2}\end{array}$} \\
\hline \multicolumn{3}{|c|}{ Składniki (w \% wagowych) } \\
\hline & $\begin{array}{c}\text { Próbka } 1 \\
\text { korpus }\end{array}$ & $\begin{array}{c}\text { Próbka } 2 \\
\text { ornament, żółta nić }\end{array}$ \\
\hline $\mathrm{SiO}_{2}$ & 62,68 & 52,66 \\
\hline $\mathrm{Na}_{2} \mathrm{O}$ & 14,42 & 10,36 \\
\hline $\mathrm{K}_{2} \mathrm{O}$ & 4,12 & 3,19 \\
\hline $\mathrm{CaO}$ & 6,29 & 4,82 \\
\hline $\mathrm{MgO}$ & 3,39 & 2,51 \\
\hline $\mathrm{Al}_{2} \mathrm{O}_{3}$ & 4,31 & 3,99 \\
\hline $\mathrm{FeO}$ & 0,56 & 0,59 \\
\hline $\mathrm{MnO}$ & 1,85 & 0,35 \\
\hline $\mathrm{Sb}_{2} \mathrm{O}_{5}$ & - & - \\
\hline $\mathrm{PbO}$ & 0,45 & 16,65 \\
\hline $\mathrm{CoO}$ & - & - \\
\hline $\mathrm{CuO}$ & - & - \\
\hline $\mathrm{BaO}$ & - & - \\
\hline $\mathrm{TiO}_{2}$ & 0,02 & 0 \\
\hline $\mathrm{SnO}_{2}$ & 0 & 2,55 \\
\hline $\mathrm{SrO}$ & - & - \\
\hline $\mathrm{NiO}$ & 0 & 0,36 \\
\hline $\mathrm{ZnO}$ & 0,12 & 0,81 \\
\hline $\mathrm{As}_{2} \mathrm{O}_{5}$ & 0,87 & 0,52 \\
\hline $\mathrm{P}_{2} \mathrm{O}_{5}$ & 0,54 & 0,65 \\
\hline $\mathrm{SO}_{3}$ & 0,08 & 0 \\
\hline $\mathrm{Cl}$ & 0,25 & 0,78 \\
\hline $\mathrm{Au}_{2} \mathrm{O}_{3}$ & - & - \\
\hline $\mathrm{Ag}_{2} \mathrm{O}$ & - & - \\
\hline $\mathrm{Cr}_{2} \mathrm{O}_{3}$ & 0,07 & 0,22 \\
\hline
\end{tabular}

- zawartość pierwiastka poniżej granicy wykrywalności 
Tabela 2. Kruszwica, stan. 4. Proporcje i sumy głównych składników szkłotwórczych szkła sodowo-potasowo-wapniowo-magnezowo-glinowo krzemowego (próbka 1) i sodowo-potasowo-wapniowo-magnezowo-glinowo-ołowiowo-krzemowego (próbka 2)

\begin{tabular}{|c|c|c|}
\hline Przedmiot & \multicolumn{2}{|c|}{ fragment szklanego paciora } \\
\hline Nr inw. & \multicolumn{2}{|c|}{ K4/6276/1968 } \\
\hline Chronologia zespołu & \multicolumn{2}{|c|}{ ostatnia ćwierć XI w. } \\
\hline Barwa i przezroczystość szkła & \multicolumn{2}{|c|}{$\begin{array}{c}\text { szkło korpusu słabo przejrzyste, } \\
\text { ornamentu opakowe, } \\
\text { barwa korpusu czarna, ornamentu żółta } \\
\text { i biała }\end{array}$} \\
\hline \multicolumn{3}{|c|}{ Składniki } \\
\hline & $\begin{array}{c}\text { Próbka } 1 \\
\text { korpus }\end{array}$ & $\begin{array}{c}\text { Próbka } 2 \\
\text { żółta nić }\end{array}$ \\
\hline $\mathrm{K}_{2} \mathrm{O}+\mathrm{Na}_{2} \mathrm{O}$ & 18,54 & 13,55 \\
\hline $\mathrm{Na}_{2} \mathrm{O} / \mathrm{K}_{2} \mathrm{O}$ & 3,5 & 3,24 \\
\hline $\mathrm{CaO} / \mathrm{MgO}$ & 1,85 & 1,92 \\
\hline $\mathrm{CaO}+\mathrm{MgO}$ & 9,68 & 7,33 \\
\hline $\mathrm{K}_{2} \mathrm{O}+\mathrm{Na}_{2} \mathrm{O} / \mathrm{CaO}+\mathrm{MgO}$ & 1,91 & 1,84 \\
\hline $\mathrm{SiO}_{2}+\mathrm{Al}_{2} \mathrm{O}_{3}+\mathrm{CaO}+\mathrm{MgO}+\mathrm{FeO} /\left(\mathrm{K}_{2} \mathrm{O}+\mathrm{Na}_{2} \mathrm{O}\right)$ & 4,16 & 4,76 \\
\hline $\mathrm{SiO}_{2}+\mathrm{Al}_{2} \mathrm{O}_{3}+\mathrm{FeO}$ & 67,55 & 57,24 \\
\hline $\mathrm{SiO}_{2}+\mathrm{Al}_{2} \mathrm{O}_{3}+\mathrm{FeO} /\left(\mathrm{K}_{2} \mathrm{O}+\mathrm{Na}_{2} \mathrm{O}\right)$ & 3,64 & 4,22 \\
\hline $\mathrm{SiO}_{2}+\mathrm{Al}_{2} \mathrm{O}_{3}+\mathrm{CaO}+\mathrm{MgO}+\mathrm{FeO} /\left(\mathrm{K}_{2} \mathrm{O}+\mathrm{Na}_{2} \mathrm{O}+\mathrm{PbO}\right)$ & 4,06 & 2,13 \\
\hline$\left(\mathrm{SiO}_{2}+\mathrm{Al}_{2} \mathrm{O}_{3}+\mathrm{FeO}\right) /\left(\mathrm{K}_{2} \mathrm{O}+\mathrm{Na}_{2} \mathrm{O}+\mathrm{PbO}\right)$ & 3,55 & 1,89 \\
\hline $\mathrm{K}_{2} \mathrm{O}+\mathrm{Na}_{2} \mathrm{O}+\mathrm{PbO} / \mathrm{CaO}+\mathrm{MgO}$ & 1,96 & 4,16 \\
\hline $\mathrm{K}_{2} \mathrm{O}+\mathrm{Na}_{2} \mathrm{O}+\mathrm{PbO}$ & 18,99 & 30,2 \\
\hline $\mathrm{K}_{2} \mathrm{O}+\mathrm{Na}_{2} \mathrm{O} / \mathrm{PbO}$ & 41,2 & 0,81 \\
\hline $\mathrm{SiO}_{2} / \mathrm{PbO}$ & 139,28 & 3,16 \\
\hline $\mathrm{SiO}_{2} /(\mathrm{CaO}+\mathrm{MgO})$ & 6,47 & 7,18 \\
\hline $\mathrm{Al}_{2} \mathrm{O}_{3}$ & 4,31 & 3,99 \\
\hline $\mathrm{K}_{2} \mathrm{O} / \mathrm{K}_{2} \mathrm{O}+\mathrm{Na}_{2} \mathrm{O} \times 100$ & 22,22 & 23,54 \\
\hline $\mathrm{MgO} / \mathrm{CaO}+\mathrm{MgO} \times 100$ & 35,02 & 34,24 \\
\hline
\end{tabular}

szkła tego samego typu $\mathrm{z}$ dodatkiem tlenku ołowiu $\left(\mathrm{Na}_{2} \mathrm{O}-\mathrm{K}_{2} \mathrm{O}-\mathrm{CaO}-\mathrm{MgO}-\mathrm{Al}_{2} \mathrm{O}_{3}-\right.$ $-\mathrm{PbO}-\mathrm{SiO}_{2}$ ), prawdopodobnie pełniącego $\mathrm{w}$ tym przypadku również rolę środka zamącającego (wraz z związkami cyny) i barwiącego na żółto. Koncentracja PbO w tym przypadku jest wysoka (16,65\%), dolna granica stężenia, powyżej której uwzględnia się ołów w typie chemicznym szkła, wynosi 5\%, wpisano więc tlenek ołowiu do formuły (bliżej o różnej roli ołowiu, wątpliwościach i zasadności wpisania go do formuły szkła tego typu - Dekówna 1980, s. 79; Dekówna i Purowski 2012, s. 140-142).

Szczegółowe kryteria podziału szkieł sodowych odmiany ,popiołowej” zamieściły w swoich pracach - J.L. Szczapowa (1973, s. 19 i nn.; 1975, s. 37 i nn.), Maria Dekówna (1980, s. 31) i Teresa Stawiarska (1984, s. 23). Opierając się na 
tych ustaleniach i przedstawionych w tabeli 2 wybranych sumach i proporcjach głównych składników szkłotwórczych, można zrekonstruować podstawowe normy recepturowe, według których wytopiono szkło ${ }^{6}$. Jeden z ważniejszych współczynników - suma alkaliów podzielona przez sumę pierwiastków ziem alkalicznych czyli $\mathrm{Na}_{2} \mathrm{O}+\mathrm{K}_{2} \mathrm{O} / \mathrm{CaO}+\mathrm{MgO}$ określa podstawowy skład zestawu szklarskiego. Jeśli suma ta jest mniejsza niż 3 (tak jak w przypadku paciora z Kruszwicy 1,91 dla korpusu i 1,84 dla żółtej nici), można przypuszczać, że szkło mogło być wytopione z zestawu trójskładnikowego - piasku, surowca wapniowego i topników (alkaliów), liczba ta określa również szkło jako średnioalkaliczne. Jednak te dane mogą być jedynie przesłanką do takich rozważań - $\mathrm{CaO}$ może pochodzić z bogatych w $\mathrm{CaO}$ i $\mathrm{MgO}$ piasków lub być sumą ich zawartości w piaskach i zastosowanych popiołach (bliżej - Dekówna 1980, s. 37; Dekówna i Purowski 2012, s. 111). Współczynnik $\mathrm{MgO} / \mathrm{CaO}+\mathrm{MgOx} 100$ dla surowca wapniowego pozwala na określenie podstawowych, stosowanych surowców. Jednak i tu taka analiza w przypadku szkieł sodowych popiołowych jest utrudniona z powodów wspomnianych powyżej. Korzystając z ustaleń T. Stawiarskiej (1984, ryc. 3, s. 35-37), można więc jedynie przypuszczalnie określić intencjonalnie dodany surowiec wapniowy jako dolomit. Zawartość MgO powyżej 2\% (dla osnowy paciora z Kruszwicy 3,39\%, żółtej nici - 2,51\%) pozwala wpisać go do formuły określającej typ chemiczny szkła. Prawdopodobnie został wprowadzony do zestawu wraz z surowcem wapniowym i popiołem z roślin halofitowych.

Jako środka odbarwiającego, wspomagającego również lepsze przyswojenie barwników szkła osnowy i ornamentu, użyto stosowane od starożytności w pracowniach wschodnich związki arsenu $\mathrm{As}_{2} \mathrm{O}_{3}$ (Galibin 2001, s. 49; Dekówna i Purowski 2016, s. 163). Jeśli jego koncentracja wynosi ponad 0,1\%, przyjmuje się, że został dodany do zestawu intencjonalnie (Dekówna i Olczak 2002, s. 196, tab. 4). W szkle paciora występuje w stężeniu 0,87\% (osnowa) i 0,52\% (ornament). Do zamącenia opakowego szkła ornamentu użyto związków cyny (SnO) i ołowiu $(\mathrm{PbO})$. Metodę zmętniania szkła związkami cyny stosowano już od okresu halsztackiego, częściej od wczesnego średniowiecza (Purowski 2012, s. 264-265); Dekówna i Purowski 2012, s. 142). Ciemną, czarno-fioletową barwę szkła korpusu nadały stosowane łącznie związki manganu $(\mathrm{MnO})-1,85 \%$ i 0,35\% i żelaza $(\mathrm{FeO})-$ 0,56\% i 0,59\% (Nowotny 1958, s. 71; Dekówna i Olczak 2002, s. 194, tab. 3). Żółtą nić ornamentu zabarwiły tlenki ołowiu, od starożytności używane jako barwniki szkła sodowego, w szkłach opakowych często występujące z cyną (Dekówna i Purowski 2012, s. 142).

Szkło sodowe, odmiany ,popiołowej”, typu sodowo-potasowo-wapniowo-magnezowo-glinowo-krzemowego $\left(\mathrm{Na}_{2} \mathrm{O}-\mathrm{K}_{2} \mathrm{O}-\mathrm{CaO}-\mathrm{MgO}-\mathrm{Al}_{2} \mathrm{O}_{3}-\mathrm{SiO}_{2}\right)$ znane jest od starożytności z terenów Egiptu, Mezopotamii, Kaukazu, również z Polski z okresu

\footnotetext{
${ }^{6}$ Receptura - przepis podający rodzaje i ilość surowców świadomie wprowadzonych do zestawu szklarskiego (bliżej omawiają to zagadnienie M. Dekówna (1980, s. 35), T. Stawiarska (1984, s. 22).
} 
halsztackiego. Wraz ze szkłem z tej samej grupy technologicznej, typu $\mathrm{Na}_{2} \mathrm{O}-\mathrm{K}_{2} \mathrm{O}-$ - $\mathrm{CaO}-\mathrm{MgO}-\mathrm{SiO}_{2}$, różniącej się jedynie większym stężeniem pochodzącego z piasku tlenku glinu, mają bardzo szeroki zasięg. Reprezentują starożytną, bliskowschodnią recepturę, o szerokim zasięgu, często stosowaną w okresie rzymskim. Szkła takie spotyka się we wczesnym średniowieczu w Egipcie, Mezopotamii, Azji Przedniej, na Kaukazie, w Bułgarii, Słowacji, w Europie Północnej i na Rusi. Wytapiano je w bliskowschodnich ośrodkach muzułmańskich oraz pracowniach bizantyńskich, również prowincjonalnych. W okresie wczesnego średniowiecza szkło obu typów stosowano w pracowniach północnej Europy, które przetwarzały importowany surowiec. Ślady takiego przetwórstwa odkryto w pracowniach w Haithabu, w Starej Ładodze czy bułgarskim Presławiu (za Dekówna 1980, s. 141-144; Dekówna i Purowski 2012, s. 95, 145 i tam źródłowa literatura) ${ }^{7}$. Jeden z współczynników, suma $\mathrm{Na}_{2} \mathrm{O}+\mathrm{K}_{2} \mathrm{O}$ do $\mathrm{CaO}+\mathrm{MgO}$, obliczony dla obu próbek szkła paciora z Kruszwicy, wyraża się stosunkiem około $2: 1$. Jest to współczynnik określony przez J.L. Szczapową jako charakterystyczny dla szkieł bizantyńskich (Dekówna 1980, s. 103; Szczapowa 1983, 45-46). O wschodnim pochodzeniu szkła, z którego wytworzono pacior z Kruszwicy, może świadczyć również obecność związków manganu (MnO), używanego w pracowniach bizantyńskich także jako odbarwiacz masy szklanej (Szczapowa 1988, s. 79).

\section{ZŁOŻONE ZAGADNIENIE POCHODZENIA}

Paciorki wykonane ze szkła koloru czarnego zdobione wielobarwnymi guzkami i linią falistą spotyka się już w inwentarzach z okresów wpływów rzymskich i wędrówek ludów. Podobnie jak znacznie później, we wczesnym średniowieczu, są to przeważnie duże okazy, nieprzekraczające jednak 2-2,5 cm długości (Tempelmann-

\footnotetext{
${ }^{7}$ Posiłkując się tabelami porównawczymi z proporcjami i sumami głównych składników szkłotwórczych dla wczesnośredniowiecznych szkieł sodowych, „popiołowych”, typu $\mathrm{Na}_{2} \mathrm{O}-\mathrm{K}_{2} \mathrm{O}-\mathrm{CaO}-\mathrm{MgO}-$ $-\mathrm{Al}_{2} \mathrm{O}_{3}-\mathrm{SiO}_{2}$, publikowanymi przez M. Dekównę, można stwierdzić ogólne podobieństwa do szkieł pochodzących z różnych ośrodków, w tym również z pracowni północnej Europy. Najbardziej zbliżone wartości mają naczynia datowane na X-XIII wiek z Bajłakanu i Tbilisi na Kaukazie czy z Uzgen w Dolinie Fergańskiej (Dekówna 1980, tab. 35:19, 20, 23) - pracownie bliskowschodnie? Analizy nieudanych wyrobów pracowni szklarskich w Wolinie, wytwarzających od 2. połowy X do 1. połowy XI wieku paciorki typu bisier i segmentowe wykazały, że przetwarzano tam m.in. szkło typu $\mathrm{Na}_{2} \mathrm{O}-$ $-\mathrm{K}_{2} \mathrm{O}-\mathrm{CaO}-\mathrm{MgO}-\mathrm{Al}_{2} \mathrm{O}_{3}-\mathrm{SiO}_{2}$ (Kokora 2019a; 2019b). Brak jest jednak widocznych podobieństw do szkła paciora z Kruszwicy. W pracowniach w Haithabu używano importowanego surowego szkła (raw glass), również typu $\mathrm{Na}_{2} \mathrm{O}-\mathrm{K}_{2} \mathrm{O}-\mathrm{CaO}-\mathrm{MgO}-\mathrm{Al}_{2} \mathrm{O}_{3}-\mathrm{SiO}_{2}$ niekiedy zamąconego cyną. Odkryto tam odpady produkcyjne i nieudane wyroby $\mathrm{z}$ takiego szkła. Jednak zbliżone wartości zaobserwowano jedynie w przypadku szafirowego paciorka (Dekówna 1980, s. 180, 186, tab. 41, tab. 51:5). Tylko podobne są również wartości - surowca wapniowo-magnezowego paciorka odcinkowego z Janowa Pomorskiego (Dekówna i Purowski 2012, tab. 15) czy jednej z warstw odcinkowego paciorka z metalową folią z cmentarzyska w Dziekanowicach (Dekówna i Purowski 2019, tab. 6). Autorzy nie wykluczają produkcji tych paciorków w jednej z pracowni nadbałtyckich (przypuszczalnie w Starej Ładodze czy Haithabu).
} 
-Mączyńska 1985, taf. 7:1-3, o produkcji rzymskich czarnych szkieł, również biżuterii - bliżej Cosyns 2011). Dla paciorków tego typu z okresu wczesnego średniowiecza można posiłkować się wyczerpującą typologią Johanna Callmera (1977). Trzeba jednak podkreślić, że wielkość paciora z Kruszwicy i jego finezyjny ornament nie są analogiczne do okazów zarówno przez tego badacza uwzględnionych, jak i zaprezentowanych poniżej. Egzemplarz kruszwicki jest większy od przeciętnych okazów z typologii J. Callmera, ma formę elipsoidalną i inne barwy ornamentów. Można przyjąć, że reprezentuje „rozbudowaną” odmianę powszechniej występujących okazów. Paciorki takie, według J. Callmera (grupa B088 i B090), to mała, ale wyraźna grupa lekko spłaszczonych okazów z guzkami, średniej wielkości. Należy dodać, że guzki występują w różnych wariantach zdobniczych, ornament nici jest przeważnie biały, a guzków biało-czerwony. Zawsze występujące w tego typu paciorkach ciemne szkło jest nierzadko ciemnofioletowe. Paciorki takie występują na obszarach basenu Morza Bałtyckiego w późnym X wieku i początkach wieku XI, w Europie Wschodniej i Południowo-Wschodniej. Rzadko spotykane są natomiast na terenach Europy Zachodniej, ale są znane z Islandii. Do tych okazów nawiązują paciorki odkryte w faktorii w Hathabu (Steppuhn 1998, s. 47, taf. 1-5, Farbtafel 3:127).

J. Callmer wyklucza bizantyjskie czy ewentualnie ruskie pochodzenie tego typu paciorków oraz miejscową ich produkcję w nadbałtyckich warsztatach przetwórczych. Wskazuje na ich orientalne pochodzenie, a ściślej na zachodni Turkiestan jako prawdopodobne miejsce produkcji (Callmer 1977, s. 85-86, 97, plate 6, colour plate I; 1997, plate 18). Podobnie, analizując analogiczne paciorki z cmentarzyska w Haithabu, cmentarzysk skandynawskich w Tuna i Badelunda, twierdzi Matthew C. Delvaux (2017, fig. 9 i 12, s. 23), ostrożnie lokując pracownie, z których pochodzą tego typu paciorki, na Bliskim Wschodzie i jednocześnie podkreślając ich występowanie wzdłuż dalekosiężnych szlaków handlowych.

Opinię tę potwierdzają znaleziska z leżącego na nadwołżańskim szlaku Bolgaru (Valiulina 2017, 391, abb. 1:2). Autorka ta łączy tego rodzaju paciorki z X-XI wiekiem, z pracowniami w Syrii lub Mezopotamii. Również z cmentarzyska w Minino i Minino 2 pochodzą podobne XI-wieczne paciorki ze zdobionymi guzkami, jednoznacznie łączone przez badaczy rosyjskich z warsztatami bizantyjskimi i zaliczone do pierwszej, wczesnej fali napływu m.in. takich również rzadko tam spotykanych okazów (Zakharov i Kuzina 2008, s. 161, ryc. 143).

J.L. Szczapowa, znająca pacior kruszwicki z autopsji, łączy go z warsztatami północnego Krymu i zwraca uwagę na występowanie podobnych okazów w kurhanach chazarskich ${ }^{8}$. Uproszczona typologia paciorków z tych obiektów, prezentowana przez S.A. Pletniewą (1989, s. 113-121, ryc. 65), obejmuje kilka typów paciorków ze zdobionymi guzkami, różniących się jednak od paciora z Kruszwicy.

\footnotetext{
${ }^{8}$ Uwagi J.L. Szczapowej zarejestrowane podczas jej pobytu w 1978 roku w Poznaniu i spotkania z Jerzym Olczakiem.
} 
Na obszarze Rusi Kijowskiej paciorki z ornamentem zdobionych guzków i falistej nici, zdecydowanie mniejsze, cylindryczne, znane są m.in. z Nowogrodu (gdzie występują do początków XI wieku), Starej Ładogi, Sarkieła i z wiatyckich kurhanów (Szczapowa 1956, s. 178, tab. II:25). Odkryto je również w Kijowie pod fundamentami Dziesięcinnej Cerkwi. Badacze rosyjscy łączą je z pracowniami bliskowschodnimi (Szczapowa 1972, s. 177, ryc. 33:15).

Podobny, kulisty okaz, z guzkami zdobionymi biało-czerwonym ornamentem millefiori i białą nicią, pochodzi ze Strahova w Czechach, gdzie jest również znaleziskiem rzadkim (Černa, Hulinsky, Tomkovâ i Cilovà, 2003, s. 335-339, plate 105:II.2, tab. 1). Został przebadany fizykochemiczne, a wyniki analizy składu chemicznego szkła wykazały zbliżone koncentracje składników szkłotwórczych tego samego typu szkła sodowego, ,popiołowego” co szkło paciora z Kruszwicy $\left(\mathrm{SiO}_{2}-\right.$ $69,49 \%, \mathrm{Na}_{2} \mathrm{O}-10,71 \%, \mathrm{~K}_{2} \mathrm{O}-6,43 \%, \mathrm{CaO}-4,04 \%, \mathrm{FeO}-2,69 \%, \mathrm{Al}_{2} \mathrm{O}_{3}-$ $3,15 \%, \mathrm{MgO}-1,15 \%$, i tylko ta ostatnia wartość jest wyraźnie niższa). Podobny, ale mniejszy okaz z cmentarzyska z VIII-XI wieku w Borovcach k. Trnawy (Słowacja), bardziej spłaszczony, z ornamentem czerwonych guzków i białej falistej nici, również przebadano fizykochemicznie. Paciorek wykonano ze szkła typu PbO$-\mathrm{SiO}_{2}$ (ołowiowego, bezalkalicznego), barwnikiem był tlenek żelaza (Staššiková-Štukovská i Plško 1997, plate 21, tab. 4, s. 268). Te dwie analizy wskazują, że podobne do siebie pod względem formalnym paciorki wykonano ze szkła wytopionego z odmiennych surowców. Badacze czescy uważają ten typ paciorków występujących tam w X-XI wieku za bezsporny import (Krumphanzlová 1965, s. 175-176).

M. Dekówna przedstawiła w ostatnich swoich pracach $(2017$; 2018) wyniki badań nad rzadkimi okazami dużych czarnych paciorków, zdobionych falistą linią wykonaną ze szkła innej barwy. Są to okazy różniące się kształtem i rozmiarami od zdobionego dodatkowo wypukłymi guzkami egzemplarza z Kruszwicy. Łączy je jedynie ciemna, niekiedy czarna barwa korpusu i faliste linie zdobiny. Podobnie jak okazy z guzkami, znane są już od okresu wpływów rzymskich i mają szeroki zasięg terytorialny. Interesujące spostrzeżenia, dotyczące podobnych okazów pochodzących z IV-VI wieku z terenu Anglii, zamieściła w swojej pracy Sue Heaser. Rzadkie znaleziska takich paciorków łączy z pobytem legionów rzymskich, w których służyły oddziały żołnierzy pochodzących z Syrii (bliżej Heaser 2020).

Szczególnie interesujące jest znalezisko paciorka z nadwołżańskiego Bołgaru, wielkiego wczesnośredniowiecznego ośrodka, leżącego na szlaku handlowym między Wołgą a Morzem Bałtyckim. Z prowadzonych tam badań wykopaliskowych pochodzi duża kolekcja szklanych paciorków (Valiulina 2017, s. 391). Przedstawiony w pracy M. Dekówny okaz pochodzi jednak z niedatowanej kolekcji muzealnej. Wyniki badań chemicznego składu szkła tego paciorka wykazały, że wykonano go ze szkła sodowego, ,popiołowego" tego samego typu co pacior z Kruszwicy (Dekówna 2018, tab. 11 i 12, ryc. 45). Zarówno koncentracje głównych składników szkłotwórczych, jak i ich główne sumy i proporcje w szkle 
korpusu są bardzo zbliżone. Autorka przychyla się do słabo udokumentowanych teorii o produkcji takich paciorków na Bliskim Wschodzie już od czasów rzymskich i prawdopodobnie w ośrodkach bizantyńskich we wczesnym średniowieczu.

\section{ZAKOŃCZENIE}

Przytoczone powyżej przykłady nie dają do końca wystarczających i bezspornych podstaw do formułowania wniosków dotyczących regionu czy ośrodka, w którym wytopiono szkło i gdzie wykonano pacior kruszwicki. Interpretacja wyników analizy składu chemicznego szkła pozwala jednak na przypuszczenie, że szkło wytopiono w jednym z ośrodków wytwórczych (w hucie) na Bliskim Wschodzie, a ściślej w jednej z pracowni bizantyńskich lub prowincjonalnobizantyńskich. Sama forma paciora, nawiązująca do starszych rzymskich okazów, występuje na wielu stanowiskach wczesnośredniowiecznych, głównie w basenie Morza Bałtyckiego, na Rusi, w północnej Europie. Badacze łączą jednomyślnie wszystkie te rzadko odkrywane okazy z pracowniami z Bliskiego Wschodu. Paciorki z płasko wtopionymi „oczkami” czy guzkami, różnych odmian, nierzadko określane są jako charakterystyczne dla warsztatów bizantyńskich czy islamskich. Nazwę - paciorki z okresu islamskiego - stosuje się do klasyfikowania wyrobów z określonych obszarów geograficznych i okresów z rozpoznawalnymi cechami, w tym technikami wytwarzania i zdobinami. Ogólnie można stwierdzić, że powstały na Bliskim Wschodzie między VII a XII wiekiem i reprezentują szeroką gamę stylów zdobniczych i technik wykonania, między innymi technikę millefiori i jedną z najczęściej spotykanych technik formowania paciorków - nawijanie pasma szkła na trzpień. Charakteryzują je m.in. częste użycie kontrastowych kolorów - w tym czerni i bieli, do czego nawiązywali również rzemieślnicy bizantyńscy (Spaer 2001; Liu 2002). Również i te ogólne uwagi wnoszą nowe dane do rozważań o pochodzeniu paciora z Kruszwicy. Można ostrożnie stwierdzić, że zarówno typ chemiczny szkła, jak i rodzaj zastosowanego ornamentu można łączyć z wschodnimi pracowniami szklarskimi.

Problem napływu na ziemie polskie wyrobów pochodzenia wschodniego, ruskiego czy bizantyńskiego jest szeroko omawiany na łamach literatury naukowej przez badaczy zajmujących się tym tematem. W przypadku ,wędrówki” szklanego paciora, odkrytego w Kruszwicy, trzeba wspomnieć o zasadniczych przemianach $\mathrm{w}$ organizacji handlu, również dalekosiężnego, jednego z podstawowych filarów ówczesnej gospodarki. Handel ten obsługiwany był od czasów pierwszej monarchii piastowskiej przez obcych kupców - głównie skandynawskich czy później przybywających z Rusi Kijowskiej (Łosiński 1996, s. 173-176). Między XI a XII wiekiem przestali pojawiać się wędrowni kupcy, a zaczęły powstawać faktorie kupieckie. Wymiana dalekosiężna zaczęła mieć charakter stały, a wymiana lokalna przybrała na intensywności - powstawały nowe osady targowe i miasta, nastąpiła 
intensyfikacja różnych dziedzin wytwórczości (Trawkowski 2005, s. 236-237). Grupy obco etnicznych przybyszy (głównie kupców) zajmowały istotne miejsce w strukturze społecznej ośrodków wczesnomiejskich. Te zmiany można zaobserwować, analizując materiały z ośrodka w Kruszwicy, gdzie powstanie faktorii kupieckiej przypisuje się przybyszom z Rusi Kijowskiej (Dzieduszycki 1982 s. 116-117). Stymulują oni aktywność handlową ośrodka, leżącego na jednym z głównych szlaków „wschodnich” biegnących z Rusi na Pomorze. Jedną z hipotez jest łączenie obecności rzemieślników z Rusi Kijowskiej z budową kościoła św. Wita, wyposażonego w szkliwione posadzki (Olczak 1968, s. 218 i nn.).

Pozostałościami po tych relacjach są obce elementy kultury materialnej, świadczące o intensywnych kontaktach - pośrednich bądź bezpośrednich. W zabytkowym materiale z Kruszwicy wyraźnie widoczny jest zespół zabytków powstałych w bizantyńsko-ruskim kręgu kulturowym?. O importowanej ceramice pisał W. Dzieduszycki (1997), o ceramice glazurowanej, w tym glinianych szkliwionych pisankach Jarmila Kaczmarek (1997). Ołowiana pieczęć kijowskiego księcia Wsiewołoda-Andrzeja była tematem opracowania Andrzeja Poppe (1979). Jednym z ważniejszych wyznaczników takich kontaktów handlowych są przęśliki z różowego łupku owruckiego (Wołoszyn 2007, s. 186). W Kruszwicy odkryto ich kilkanaście. Trzeba jeszcze wspomnieć o ułamku rzadko występującej na terenach zachodniosłowiańskich szklanej bransolety, miniaturowym żelaznym toporku z brązowymi wypustkami identyfikatorze określonej grupy społecznej, jaką byli drużynnicy, czy sprzączce lirowatej. Szczególnie cennym znaleziskiem jest wydobyty z grobu dostojnika kościelnego przy kolegiacie św. Piotra złoty krzyżyk-zawieszka typu bizantyńskiego (Dzieduszycki 2009, s. 425).

\section{BIBLIOGRAFIA}

Barkoudah Y., Henderson J. 2006, Plant ashes from Syria and the manufacture of ancient glass: ethnographic and scientific aspects, ,Journal of Glass Studies” 48, s. 297-321.

Callmer J. 1977, Trade beads and bead trade in Scandinavia ca. 800-1000, "Acta Archaeologica Lundensia" 4/11, Lund.

- 1997, Beads and bead production In Scandinavia and the Baltic Region c. A.D 600-1100, a general outline, w: U. von Freeden, A. Wieczorek (hrsg.), Perlen. Archäeologie. Techniken. Analysen, Bonn, s. $97-202$.

Cofta-Broniewska A. 1962, Z zagadnień obróbki metali nieżelaznych, „Slavia Antiqua”, t. 9, s. 273-299.

Cosyns P. 2011, The production, distribution and consumption of black glass in the Roman Empire during the 1st-5th century AD. An archaeological, archaeometric and historical approach, Brussel.

Černa E., Hulinsky V., Tomkovâ K., Cilovà Z. 2003, Early medieval glass beads from Prague Castle and its surroundings - typological and chemical classification of the finds, Annales du 16e Congrès de l'Association Internationale pour l'Histoire du Verre, London, s. 335-339.

Dekówna M. 1980, Szkło w Europie wczesnośredniowiecznej, Wrocław-Warszawa-Kraków-Gdańsk.

\footnotetext{
${ }^{9}$ Pochodzenie ruskie czy bizantyńskie? O przynależności kulturowej zabytków z kręgu rusko-bizantyńskiego, pojmowaniu tego zjawiska i wyjaśnieniu klasyfikacji pisze Marcin Wołoszyn (2006).
} 
- 2005, Rozwój metod badania znalezisk szkła w Polsce, „Acta Universitatis Nicolai Copernici”, „Archeologia” 29, „Archeologia szkła” 9, s. 3-40.

- 2017, Pochodzenie sporadycznie wystęujacych na obszarze Polski dużych paciorków z ciemnego szkła $w$ świetle badań laboratoryjnych, w: D. Adamska, K. Chrzan, A. Pankiewicz (red.), Cum gratia et amicitia. Studia dedykowane Pani Profesor Marcie Młynarskiej-Kaletynowej z okazji 65-lecia działalności naukowej, Wrocław, s. 159-171.

- 2018, Bead variety of dark glass decorated with glass thread. Problems of origin and chronology, w: D. Staššíková-Štukovská (ed.), Historické sklo. Multidisciplinárne o historickom skle III, Bratysława, s.127-144.

Dekówna M., Olczak J. (red.) 2002, Principes de description des verres ancien depuis les temps les plus reculés jusq'au XIII siécle de n.é., Warszawa-Toruń.

Dekówna M., Purowski T. 2012, Znaleziska związane ze szklarstwem oraz okazy z kwarcu ze stanowiska Janów Pomorski, w: M. Bogucki, M.F. Jagodziński (red.), Janów Pomorski stan. 1. Wyniki ratowniczych badań archeologicznych w latach 2007-2008, I:3. Analizy, Elbląg, s. 66-260.

- 2016, Paciorki szklane, w: A. Buko (red.) Bodzia. Elitarny cmentarz z początków państwa polskiego, Warszawa, s. 153-206.

- 2019, Biżuteria szklana z cmentarzyska w Dziekanowicach, w: J. Wrzesiński (red.), Groby z biżuteria wczesnośredniowiecznego cmentarzyska w Dziekanowicach, Fontes. Biblioteka Studiów Lednickich, seria B1, t. 8:1, Lednica, s. 261-358.

Delvaux M.C. 2017, Patterns of Scandinavian bead use between the Iron Age and Viking Age, ca. 600-1000 c.e., „Beads. Journal of the Society of Bead Researches”, vol. 29, s. 3-24.

Dzieduszyccy B. i W. 1993, Kruszwicki ośrodek władzy i jego przemiany w XI-XIII wieku, w: S. Moździoch (red.), Lokalne ośrodki władzy państwowej w XI-XIII wieku, Wrocław, s. 159-172.

- 2005, Dzieje piastowskiego ośrodka w Kruszwicy we wczesnym średniowieczu, w: J. Dudek (red.), Europa Środkowo-Wschodnia. Ideologia, historia a społeczeństwo, Zielona Góra, s. 457-461.

Dzieduszycki W. 1982, Wczesnomiejska ceramika kruszwicka w okresie od 2 połowy X w. do połowy XIV wieku, Wrocław-Warszawa-Kraków-Gdańsk-Łódź.

- 1984, Socjotopograficzne przeobrażenia wczesnośredniowiecznych miast polskich (model kruszwicki), „Kwartalnik Historii Kultury Materialnej”, R. 32/1, s. 3-21.

- 1997, Imported ceramics in early-mediaeval polish lands. Apperance. Character. Interpretation, w: A. Buko (red.) Imported and Locally Produced Pottery, Warszawa, s. 73-81.

- 2008, Kruszwica, piastowska domena nad Goptem, w: M. Kobusiewicz (red.), Pradzieje Wielkopolski, Poznań, s. 397-431.

Galibin W.A. 2001, Sostav stiekła kak archieołogičeskij istočnik. Ars vitraria experimentalis. Sankt-Peterburg.

Heaser S. 2020, Dark ellipsoid beads with opaque glass thread decoration found in Britain, „Archeologia Polski” 65, s. 115-129.

Henderson J. 2013, Ancient Glass an Interdisciplinary Exploration, Cambridge.

Kaczmarek J. 1997, Early mediaeval glazed pottery of great Poland: import or local product, w: A. Buko (red.), Imported and Locally Produced Pottery, Warszawa, s. 63-71.

Kokora K. 2019a, Szklarstwo wczesnośredniowiecznego Wolina wedtug Jerzego Olczaka i Elżbiety Jasiewiczowej - 55 lat później. Nowe ustalenia dotyczace przedmiotów szklanych ze stan. 1 w Wolinie, „Archeologia Polski”, t. 64, s. 283-338.

Kokora K. 2019b, Glass Artefacts, w: M. Rębkowski (ed.), Wolin. The Old Town, vol. 2, Studies on finds, Szczecin, s. 191-221.

Krumphanzlová Z. 1965, Skleněné perly doby hradištni v Čechach, „Památky archeologické”, 56/1, S. 161-188.

Liu R.K. 2002, Islamic Glass Beads. The Well - Traveled Ornament. www.academia.edu/36642491/Islamic_Glass_Beads.

Łosiński W. $199 \overline{6}$, Miejsce Pomorza i Wielkopolski w kształtowaniu się gospodarki towarowo-pieniężnej w Polsce wczesnofeudalnej, „Slavia Antiqua”, t. 37, s. 163-180.

Nowotny W. 1958, Szkla barwne, Warszawa. 
Olczak J. 1968, Wytwórczość szklarska na terenie Polski we wczesnym średniowieczu. Studium archeologiczno-technologiczne, Wrocław-Warszawa-Kraków.

Pletnieva S.A., 1989, Na slaviano-chazarskom pogranicze. Dmitrievskij archeologicheskij kompleks, Moskva.

Poppe A. 1979, Pieczęć ruska z Kruszwicy, „Slavia Antiqua”, t. 26, s. 121-126.

Purowski T. 2012, Wyroby szklane w kulturze łużyckiej w międzyrzeczu Noteci i środkowej Odry. Studium archeologiczno-technologiczne, Warszawa.

Spaer M. 2001, Ancient Glass in the Israel Museum. Beads and Other Small Objects, Jerusalem.

Staššiková-Štukovská D., Plško A. 1997, Typologische und technologische Aspekte der Perlen aus dem Frühmittelalterlichen Gräberfeld von Borovce, w: U. von Freeden, A. Wieczorek (hrsg.), Perlen. Archeologie. Techniken. Analysen, Bonn, s. 259-274.

Stawiarska T. 1984, Szkła z okresu wpływów rzymskich z pótnocnej Polski. Studium technologiczne. Wrocław-Warszawa-Kraków-Gdańsk-Łodź.

- 1987, Metody porównań składów chemicznych szkieł zabytkowych ze szczególnym uwzględnieniem okresu wpływów rzymskich, „Acta Universitatis Nicolai Copernici”, seria „Archeologia” 12, „Archeologia szkła" 2, s. 35-50.

Steppuhn P. 1998, Die Glasfunde von Haithabu, Berichte über die Ausgrabungen in Haithabu, Bericht 32, Neumünster.

Szczapowa J.L. 1956, Stieklanyje busy drewniego Nowgoroda, „Materiały i issledowania po archieołogii SSSR” 55, Trudy nowgorodskoj archieołogiczeskoj ekspedycji, t. 1, A.B. Arcihovskoj, B.A. Kołczin (red.), Moskva, s. 164-179.

- 1972, Stieklo kijevskoj Rusi, Moskva.

- 1973, Zasady interpretacji analiz składu szkła zabytkowego, „Archeologia Polski”, t. 18/1, s. 15-72.

- 1975, La verre byzantin du Ve-XIle siécles, w: V. Čubrilovič (ed.), Srednjovekovno stakło na Balkanu (V-XV vek), Beograd, s. 33-48.

- 1983, Ocherki istorii drevnego steklodeliya (po materialam doliny Nila, Blizhnego Vostoka i Evropy), Moskva.

- 1988, Bizantijskoje stiekto. Očerki istorii, Moskva

Tempelmann-Mączyńska M. 1985, Die Perlen der römischen Kaiserzeit und der frühen Phase der Völkerwanderungszeit im mitteleuropäischen Barbaricum, Mainz am Rhein.

Trawkowski S. 2005, Opuscula Medievistica. Studia nad historia społeczna Polski wczesnopiastowskiej, Warszawa.

Wołoszyn M. 2006, Europa Środkowo-Wschodnia a cywilizacja bizantyńsko-ruska w X-XIII w. Próba interpretacji źródet archeologicznych, „Prace Komisji Środkowoeuropejskiej”, t. 14, s. 7-48.

- 2007, Miedzy Gnieznem, Krakowem a Kijowem. Archeologia o wczesnośredniowiecznych relacjach polsko-ruskich i formowaniu polsko-ruskiego pogranicza, w: M. Dębiec, M. Wołoszyn (red.), Uźródel Europy Środkowo-Wschodniej: pogranicze polsko-ukraińskie w perspektywie badań archeologicznych, Rzeszów, s. 177-206.

Valiulina S. 2017, Die Glaserzeugnisse Bolgars und ihr Verhältnis zu anderen mittelalterlichen Glasproduktionen, Annales du 20e Congrès de l'Association Internationale pour l'Histoire du Verre, 391-398, Romont.

Zakharov S.D., Kuzina I.N. 2008, Veshchevoi material Mininskogo archeologiczeskogo kompleksa: Izdelija iz stekla i kamennye busy, w: S.D. Zacharov (red.), Archeologija severnorusskoi derevni 10-13 vekov: srednevekovye poselenija i mogil'niki na Kubenskom ozere. Materialnaja kultura i chronologija 2, Moskva, s. 142-215. 